\title{
Modos de transmissão INTERGERACIONAL EM ROMANCES DA LITERATURA BRASILEIRA ATUAL
}

\author{
MODES OF INTERGENERATIONAL TRANSMISSION \\ IN OF CURRENT BRAZILIAN LITERATURE NOVELS
}

Zilá Bernd

UNILASALLE-Canoas/CNPq

Canoas, Brasil

Tanira Rodrigues Soares

UNILASALLE-Canoas

Canoas, Brasil

\section{Resumo}

$\mathrm{O}$ artigo focaliza a questão da memória intergeracional tal como ela se apresenta em algumas obras da literatura brasileira atual: Azul Corvo, de Adriana Lisboa (2014), Meus desacontecimentos, a história de minha vida com as palavras, de Eliane Brum (2014) e Olhos d'água, de Conceição Evaristo (2015). Questionam-se as apelaçôes "romance memorial", "romance de filiação" e "romance familiar", verificando sua aplicabilidade no caso dos romances mencionados, representativos da literatura no feminino no Brasil hoje. Investigam-se os modos de transmissão inter e transgeracional com ênfase para: (a) a relação das personagens com seus ascendentes; (b) as funçôes de herança e transmissão.

Palavras-chave: memória inter e transgeracional; modos de transmissão; romance memorial; romance de filiaçáo; romance parental ou familiar.

\section{Resumé}

L'article met l'accent sur la question de la mémoire transgénérationnelle telle qu'elle se présente dans les oeuvres de la littérature brésilienne actuelle: $A z u l$ Corvo, de Adriana Lisboa (2014), Meus desacontecimentos, a história de minha vida com as palavras, de Eliane Brum (2014), et Olhos d'água, de Conceição Evaristo (2015). C'est notre intention remettre en question les appellations "roman mémoriel", "roman de filliation" et "roman de famille", pour vérifier son utilisation dans le cas des romans que nous venons de mentionner et qui sont représentatifs de la littérature au fémi-

\section{Abstract}

The article focuses on the issue of intergenerational memory as it appears in some works of contemporary Brazilian literature: Azul Corvo (Crow Blue), by Adriana Lisboa (2014), Meus desacontecimentos, a história de minha vida com as palavras (My unevents: the story of my life with words), by Eliane Brum (2014) and Olhos d'água (Waterholes), by Conceição Evaristo (2015). We question the appeals "memorial novel", "filiation novel" and "family novel" by checking their applicability in the case of the novels mentioned which are representative of feminine literature in Brazil today. We investigate ways 
nin au Brésil aujourd'hui. On analysera les modes de transmission inter générationnel, en particulier (a) la relation des personnages avec leurs ascendants; (b) les fonctions de l'héritage et transmission.

Mots-clés: mémoire inter et transgerationnelle; modes de transmission; roman mémoriel; roman de filiation; roman parental ou de famille. of inter and transgenerational transmission with emphasis on (a) the relationship of the characters with their ancestors; (b) the functions of inheritance and transmission.

Keywords: inter and transgenerational memory; modes of transmission; memorial novel; filiation novel; family novel.

Romance memorial ou de família

Quase todas as sociedades abraçam o imperativo da narrativa intergeracional. Quase todas as culturas têm glorificado a passagem da tocha do velho ao jovem. Esse tem sido sempre um dever primário da memória humana - familiar, tribal e mais tarde, nacional (OZ; SALZBERGER, 2015: 14-15).

Iniciamos salientando nossa intenção de estabelecer uma distinção entre o romance memorial e o gênero que embalou milhares de leitores no final do século XIX e início do XX, o romance genealógico, ou saga, e que corresponde, na definição de Demanze (2008: 22), àquele que deseja "apreender uma história coletiva a partir de percursos individuais", ou, na definição de Massaud Moisés (1982: 469), a relatos de histórias de famílias reais, mesclando fatos verídicos e ficcionais, ou ainda no sentido de "jornada heroica", usado por Erico Verissimo (1940). O grande paradigma desse gênero é o romance $O s$ Buddenbrooks de Thomas Mann de 1901. Caudalosos, geralmente publicados em vários tomos, as sagas ou romances genealógicos empolgaram gerações em vários países, como Os Thibault, de Roger Martin du Gard, na França, publicado em 8 partes entre 1922 e 1940. Esses romances de família, que têm seu apogeu no início do século XX, apresentam um importante desgaste a partir da segunda metade desse século. O Dictionnaire du littéraire (2010), descreve o "Roman familial" como um subgênero do romance, caracterizando-se por apresentar um tema, a narração da evolução de uma família através de várias geraçóes e um modo de escritura realista (ARON; SAINT-JACQUES; VIALA, 2010: 529). Segundo Yannick Preumont, "Ele concede uma grande importância aos ritos familiares e a tudo que faz do clã uma comunidade ameaçada por relaçóes altamente conflituosas. Ele conhece variantes diversas com resultados negativos e positivos"1 (2010: 529).

\footnotetext{
1 "Il accorde une grande importance aux rites familiaux et à ce qui fait du clan une communauté que des rapports conflictuels hautement symboliques menacent. Il connaît des variantes diverses à issue négative ou positive".
} 
Esse tipo de narrativa, que se pretende totalizadora na medida em que sempre abarca a evolução de diversas gerações, focando muitas vezes em sua decadência, obedece a uma ordem cronológica linear e é geralmente narrada em terceira pessoa por um narrador onisciente. Embora, como referimos anteriormente, esse gênero entre em declínio na segunda metade do século $\mathrm{XX}$, ele não desaparece totalmente, pois o gosto pelas histórias de família persiste entre o grande público, como se pode constatar pelo interesse que despertam novelas e séries televisivas que seriam uma reedição trivial do grande romance de família que dominou a cena literária do final do século XIX à metade do século XX.

Constatamos também a revivescência desse gênero na literatura quebequense com a saga Le gồt du bonheur (2000-2001), de Marie Laberge, que conta a história de três gerações de uma família quebequense, refletindo, ao mesmo tempo, sobre o contexto e a mentalidade da comunidade em que os acontecimentos da família evoluíram, com ênfase para aspectos menos conhecidos, como o impacto da II Guerra Mundial no Canadá. Esse romance em três volumes de mais de 600 páginas cada um tornou-se best seller ao ser publicado entre 2000 e 2001. No mesmo contexto literário do Quebec, Noël Audet, em À l'ombre de l'épervier (1988), que se tornou série televisiva de sucesso, dá conta do drama de diversas geraçóes de pescadores, incluindo as primeiras greves organizadas pelos incipientes movimentos sindicais na região da Gaspésie, de onde o autor era originário.

No sul do Brasil, Luiz Antonio de Assis Brasil retoma o gênero, dando vida à saga da família Borges da Fonseca e Meneses, ao contar a história de ódio e intrigas dos fundadores do patriciado sulino com Um castelo no pampa, em três volumes: Perversas famílias (1992), Pedra da memória (1993) e Os senhores do século (1994), alterando a linearidade cronológica que caracteriza o romance de família tradicional por um jogo de intersecçóes entre passado e presente.

Constata-se que, entrando em decadência em alguns momentos, o gênero não desaparece, ressurgindo transfigurado ao longo do tempo. Contudo, a grande transformação do romance de família se dá na pós-modernidade, na esteira do romance autobiográfico e autoficcional da virada do século XX ao XXI, com o chamado "roman mémoriel" (romance memorial) no qual o foco deixa de ser a interioridade (o "eu" narrador) para ser a anterioridade (focalizando na história dos ascendentes, o narrador acaba relatando sua própria história e destacando seu papel de herdeiro de seus ancestrais ou recusando-se a estabelecer o continuum com as geraçóes precedentes). Para Régine Robin (1989), o romance memorial (ou de família, também chamado de parental) seria aquele em que 
Um indivíduo, um grupo ou uma sociedade pensa seu passado, modificando-o, deslocando-o, deformando-o, inventando lembranças, um passado glorioso, ancestrais, genealogias ou, ao contrário, lutando pela exatidáo factual, para a reconstituição do acontecimento ou sua ressurreição. (ROBIN, 1989: 48) ${ }^{2}$

Pode-se assim constatar que o romance memorial está profundamente associado à recuperação da memória cultural, ${ }^{3}$ revelando preocupação com a temática da ascendência e da ancestralidade: falar dos pais torna-se subterfúgio para falar de si próprio e de seu papel de herdeiro da tradição parental. Como afirma o escritor israelense Amós $\mathrm{Oz}$, "o herdeiro é livre para decidir o que vai escolher de sua herança” (OZ; SALZBERGER, 2015: 173).

O romance memorial está, pois, associado à preservaçáo da memória cultural, à transmissão inter e transgeracional e à postura do sujeito narrador de assumir-se como herdeiro - para dar continuidade ao patrimônio memorial herdado - ou romper com ele. Cabe lembrar que a memória geracional pode ser transmitida de uma geração à outra (intergeracional), podendo ir além dos ancestrais terrenos (pai/mãe, avô/avó), considerando-se também os Patriarcas, ou seja, a liderança espiritual cuja aceitação ou não, em algumas circunstâncias, é fundamental para que haja continuidade ou ruptura. Nesse caso, trata-se de transmissão transgeracional.

Cabe uma especificação mais detalhada a respeito da denominação: usamos aqui a apelação romance memorial ou de família. É preciso salientar, contudo, que Dominique Viart (2008: 79-102), em instigante livro sobre as caraterísticas da literatura francesa na atualidade, utiliza a apelação "romance de filiação", para falar da tendência do romance francês atual de passar do autobiográfico às narrativas de filiação que correspondem no limite à migração da "investigaçáo da interioridade em direção à da anterioridade" (2008: 79). Recomenda ainda o autor a utilização da expressão "romance de família" ao invés de romance familiar a fim de evitar confusão com o conceito de "roman familial" usado na área da psicanálise, em razão dos estudos de $S$. Freud sobre o tema. Utilizaremos para fins do presente artigo as apelaçôes romance memorial, romance de família ou de filiação, apelação também usada por Laurent Demanze, em Encres orphelines (2008). Na esteira de Dominique Viart (2008), Demanze define o romance de filiação como aquele que inverte a cronologia: a narrativa não inicia com a história de um ancestral, passando a sua descendência. Em geral, o romance é narrado por um herdeiro "proble-

\footnotetext{
${ }^{2}$ Traduçãoo das autoras.

${ }^{3}$ Memória cultural pode ser definida como aquela que incorpora os elementos que pertencem à esfera do sensível e do simbólico, os quais escapam ao registro hegemônico do poder e sua tentativa de apagar os rastros memoriais de fatos que interferem no projeto de construção da identidade nacional (BERND, 2014).
} 
mático e inquieto" que investiga a vida de um de seus ascendentes. É, portanto, o relato de uma investigação e de uma arqueologia visando à reconstituição de uma memória incerta (DEMANZE, 2008: 22-23).

Todos correspondem a uma característica atual da literatura de variadas geografias que é a de tematizar as narrativas que têm os pais ou avós como foco da investigação, usados como subterfúgio para um melhor entendimento da própria figura do narrador que constrói esse artifício ficcional para (re)pensar sua identidade.

Vale a pena conferir novamente a reflexão de Amós Oz em livro recentemente publicado no Brasil (2015) escrito em parceria com a filha Faina Oz-Salzberger, historiadora e professora na universidade de Haifa, em Israel. Em Os judeus e as palavras (2015), o pai, escritor, e a filha, historiadora, refletem sobre a transmissão das tradições judaicas, afirmando que, no judaísmo, a transmissão do que está nos livros era uma questão fundamental para a sobrevivência do grupo. Aonde quer que os judeus se deslocassem, o mais importante era levar junto os livros e fazer as crianças entrarem em contato ativo com a sabedoria neles contida desde cedo, auxiliadas pelo rabi (professor), através não somente da leitura, mas assumindo uma posição crítica em relação aos textos propostos. Assim que, segundo os autores, os judeus estão sempre "conversando" ou "brigando" com seus ancestrais desde os Pais até os Patriarcas,

ou debatendo-se com os textos que os ancestrais produziram com as ideias que os ancestrais promulgaram. Esse hábito pode ajudar a explicar o papel desse livro (no caso, os Judeus e as palavras). É por isso que nos sentimos no direito de colocar os antigos hebreus e os modernos judeus num continuum linear, não um continuum biológico, nem étnico nem mesmo religioso, mas um continuum verbal. Tantos pais produziram tantos textos para conversar com eles, polemizar contra eles ou, nos termos de (Philip) Roth, tentar em vão fazê-los calar a boca. (OZ; SALZBERGER, 2015: 46-47)

Nessa mesma linha, trafega Régine Robin, que, em seu livro Le roman mémoriel, evoca a importância de "deixar falar essa voz narrativa que vem de longe, do alhures, do neutro, em resumo, do que chamo fora-de-lugar" ${ }^{4}$ (ROBIN, 1989: 17).

\section{Modos de transmissão inter e transgeracional}

Maurice Halbwachs no clássico Mémoire collective (1997) evoca "o laço vivo das geraçôes”, expressão que, segundo Joël Candau (2014: 137), remete

\footnotetext{
4 “(...) laisser parler cette voix narrative qui vient de loin, de l'ailleurs, du neutre, bref de ce que j’appelle le hors-lieu."
} 
à memória genealógica e familiar especificando os dois tipos de genealogias: "naturalizada (relacionada ao sangue e ao solo) e simbolizada (constituída a partir de um relato fundador)". Está muito claro tanto nos textos de Halbwachs (1997), como nos de seus leitores privilegiados como Candau (2014) e Robin (1989), que a reapropriação identitária passa pela aproximação do indivíduo com a memória genealógica, tendo a transmissão um papel vital nesse processo. Salvaguardar a memória dos ancestrais corresponde a preservar sua própria identidade, adverte Candau (2014: 139).

É importante ressaltar que a memória genealógica e familiar, no entender de Candau $(2013 ; 2014)$, abrange em torno de duas a três geraçôes, caracterizando-se por ser uma memória curta e estando relacionada diretamente às questôes identitárias, isto é, à busca incessante em conhecer a trajetória dos pais e avós como forma de autoconhecimento e entendimento das suas origens. "A formulação de uma memória genealógica e, mais genericamente, de uma memória familiar, procede sempre na produção de uma identidade individual, social e cultural" (CANDAU, 2013: 175). Já a memória geracional ultrapassa o núcleo familiar e estende-se por diversas geraçóes, apresentando duas formas: a antiga e a moderna. Na forma antiga, ela é "a consciência de pertencer a uma cadeia de geraçóes sucessivas da qual o grupo ou o indivíduo se sente mais ou menos herdeiro" (CANDAU, 2014: 142). Na forma moderna, a memória geracional não tem a vocação de ser transmitida: "é própria dos membros de uma determinada geração que se autoproclama guardiôes e está fadada a desaparecer com o último deles" (2014: 142).

O romance memorial engloba em sua narrativa a memória genealógica e familiar, bem como a geracional, pois um dos fatores primordiais para sua existência e consolidação é a necessidade do (eu) narrador promover a reconstrução de trajetórias vividas por seus ascendentes e através deste processo (re)significar e/ou (re)construir o presente. É necessário o estabelecimento de um jogo dialético entre lembrar e esquecer, entre passado e presente, entre ascendentes e descendentes, entre aceitar ou renegar os vestígios memoriais que emergem.

Mas como se dá a transmissão de uma geração a outra? Anne Muxel (1996), estudando os modos de transmissão das artes de fazer da cozinha, desenvolve interessantes reflexóes sobre a arte de transmitir, de mãe para filha, as receitas familiares, afirmando que, em muitos casos, o reconhecimento dessa transmissão e da sua importância para o indivíduo e para o núcleo familiar só acontece anos mais tarde quando a que era filha torna-se mãe e se vê também na contingência de transmitir à próxima geração tal patrimônio. Assim, "o fio da memória, podendo atravessar várias geraçóes, muito do savoir-faire herdado, mas também os gostos, remontam aos avós. Os avós são em mui- 
tos casos declarados como os iniciadores de prazeres e de gostos em matéria de arte culinária" (MUXEL, 1996: 89). ${ }^{5}$ Uma das liçóes que se pode tirar da autora de Individu et mémoire familiale (MUXEL, 1996) é a de que o processo da transmissão nunca é uma equação simples: "Mesmo nos casos em que ela se estabeleceu de forma adequada, ela [a transmissão] passa por uma reapropriação de saberes e práticas. Nunca é uma reprodução de forma idêntica, ela é uma história de acomodaçóes, e em matéria de cozinha as acomodações fazem receita!”6 (MUXEL, 1996: 93).

Em algumas comunidades, transmitir é questão de sobrevivência, como entre os judeus: a sobrevivência da comunidade está na transmissão dos textos, o que vai garantir sua continuação, o continuum verbal de que fala Amós Oz:

E assim por muitos séculos as crianças judias, meninas tanto quanto meninos, foram expostas a textos escritos: um pouco de Bíblia, a estranha palavra hebraica, algumas bênçãos e oraçóes. Em qualquer dado momento duas ou três geraçóes coabitavam a mesma casa, a sinagoga, a sala de aula. E podiam passar adiante as palavras, as cançóes e os rituais. Junto com as práticas gerais de criar os filhos - formação de hábitos, treino de habilidades e narração de histórias - as velhas geraçóes tratavam de assegurar que seus filhos e netos assumissem os textos. (OZ; SALZBERGER, 2015: 33)

Vemos aqui a prática do transmitir e a importância do receber para a sobrevivência da comunidade com base no estabelecimento de um continuum que não é fundamentalmente religioso nem biológico, mas verbal e cultural.

Se em algumas culturas e em romances de família o empenho está na transmissão, que visa a preservar a "herança", em outros observam-se transmissōes imperfeitas ou falhas, assim como defeitos de transmissão. Em muitos casos, o romance memorial ou de filiação tem origem em "pais ausentes, transmissóes imperfeitas, valores caducos" (VIART, 2008: 94), constituindo-se o texto em uma tentativa de "restituição" dessa falta, enunciando-se como uma espécie de elegia ao ancestral desaparecido e cuja trajetória deixou tantas lacunas. L'Africain, de Jean Marie Le Clézio (2004), é uma tentativa do escritor de desvendar as razões do nomadismo do pai médico - o africano que permaneceu longos anos na África, tendo ficado afastado da mulher e dos filhos durante toda a Segunda Guerra Mundial. A narrativa da migrância do pai torna-se, assim, uma tentativa de entender seu próprio gosto por migraçóes e deslocamentos que o levaram a viver em vários continentes. As

\footnotetext{
5 "Fil de mémoire, pouvant traverser plusieurs générations, beaucoup de savoir-faire hérités, mais aussi des gôuts, remontent aux grands-parents. Les grands parents sont dans beaucoup des cas déclarés comme les initiateurs de plaisirs et de gôuts en la matière."

6 "Même dans les cas où elle s'avère être la mieux établie, elle passe par une réapropriation des savoirs et des pratiques. Elle n'est jamais une reproduction á l'identique, elle est une histoire d'accomodements, et en matière de cuisine, les accomodements font recette!"
} 
situaçóes de desconforto sofridas pelo pai durante os deslocamentos nos lugares mais inóspitos da África, exercendo a medicina humanitária, bem como a impossibilidade de regressar à França, o que foi motivo de sofrimento e de ressentimento da mãe e dos filhos, são exorcizadas nesse pequeno livro em que "o africano" (isto é, o que se torna estrangeiro por viver longos anos no exterior e que é praticamente desconhecido dos filhos), pouco a pouco, torna-se seu pai.

\section{O papel do ancestral (ou da ancestralidade) em narrativas} da literatura brasileira

No conto Olhos d'água (2015), que inaugura a seleta de mesmo nome de autoria de Conceição Evaristo (1946), a autora realiza magistralmente a busca do que seria a "herança" da mãe e a transmissão à filha. A dúvida da narradora, que relata em primeira pessoa, era sobre a cor dos olhos de sua mãe. Como poderia ter acontecido que ela não se lembrasse da cor dos olhos da própria mãe? A narradora vai em busca dos "espaços de recordação" de que fala Aleida Assmann (2011) e traz à tona uma série de fragmentos relativos à precariedade da situação familiar, à dificuldade da mãe em conseguir alimentar os filhos e sua imensa habilidade de disfarçar a dolorosa condição de pobreza através da contação de histórias. Lembrando detalhes da arte da mãe em driblar a desgraça da pobreza e do desamparo da vida de favelada, volta a pergunta: "Mas de que cor eram os olhos de minha mãe?" Continua lembrando que a mãe usava jogos e danças para distrair a fome dos filhos, mas não consegue lembrar a cor dos olhos da mãe. Recorda o temor da mãe em dias de chuva, temendo que o casebre não aguentasse, mas não consegue acessar os arquivos memoriais que contêm as informaçóes sobre a cor dos olhos da mãe. Lembra das Yabás "donas de tantas sabedorias".

O aspecto a ressaltar é que, as "yabás" estão entrando na narrativa como uma espécie de ancestrais/matriarcas que são aqui invocadas na tentativa de buscar ajuda para lembrar da cor dos olhos da mãe. Uma oferenda aos orixás poderia ajudá-la a desvendar o segredo. Após a longa procura, ajudada pelas orixás, descobre por que náo podia lembrar da cor dos olhos da máe: ela vê naqueles olhos só lágrimas, são os "olhos d'água" que dão título ao conto.

Minha mãe trazia, serenamente em si, águas correntezas. Por isso prantos e prantos a enfeitar o seu rosto. A cor dos olhos de minha máe era cor de olhos d'água. Aguas de mamãe Oxum! Rios calmos, mas profundos e enganosos para quem contempla a vida apenas pela superfície. Sim, águas de mamãe Oxum. (EVARISTO, 2015: 18-19)

\footnotetext{
${ }^{7}$ Iabá, Yabá ou Iyabá, cujo significado é Mãe Rainha, é o termo dado aos orixás femininos Yemanjá e Oxum (WIKIPÉDIA, 2016).
} 
O reencontro espiritual com a mãe e a conversa intergeracional enseja a conversa com a filha que por sua vez lhe pergunta: "Mãe, qual é a cor tão úmida de seus olhos?" Os olhos d'água apresenta-se como um continuum da geração da vó e da mãe, sendo que a terceira geração - a da neta - é capaz de reconhecer na mãe os olhos d'água que esta herdara de sua avó.

Já Eliane Brum (1966), em Meus desacontecimentos, a história de minha vida com as palavras (2014), associa seus medos, "seu mundo sem palavras" e suas tristes lembranças familiares com sua luta para fazer o silêncio virar narrativa até chegar a fazer das palavras seu instrumento de trabalho, já que a criança, que é personagem da história, tornar-se-á repórter e escritora.

$\mathrm{Na}$ verdade, não se trata do relato de uma memória feliz, da vida em lar harmonioso de cujos ensinamentos a narradora quer tornar-se herdeira. Trata-se antes de transmissōes imperfeitas ou falhas originadas de uma falta: ela nasce de uma mãe que perdera uma filha nascida antes dela. A mãe a levava ao túmulo da criança morta fazendo a narradora sentir "que a viva era a outra”. As lembranças da narradora são de uma casa escura e fria que ela detestava bem como as imagens do túmulo da irmá morta. Como sabemos, a partir da leitura de Jeanne Marie Gagnebin (2006: 107-118), a etimologia de túmulo é sema, a mesma de signo, e serão esses signos memoriais da devoção da mãe pela irmã morta, que impediam sua mãe de dedicar-se a ela, que impulsionarão a narradora a registrar em palavras sua infância interrompida. Essa é a razão do livro: despegar-se do papel de herdeira de uma tradição cuja transmissão é imperiosa. Toda a angústia da personagem narradora está em dotar-se da habilidade de lidar com as palavras para registrar não "acontecimentos", mas "desacontecimentos".

Como em vários romances memoriais ou de filiação, aqui não há um pacto ficcional que, segundo Galle (2014: 214), "implica que nada da narração pode ser referenciado a pessoas e a acontecimentos da realidade”. O livro enquadra-se no novo tipo de ficção - o romance memorial ou de filiação que envolve muito o leitor e acompanha a trajetória do narrador em busca do desvendamento de períodos da vida dos pais em que não estiveram presentes ou eram muito jovens para entender o que se passava. Segundo Viart (2008: 81), esse tipo de romance memorial ou de filiação hesita constantemente entre a forma romanesca e a forma autobiográfica, centrando sempre o foco na figura de um dos membros da família. No caso de Meus desacontecimentos (2014), o pai e a mãe são foco, mas também a avó com quem a narradora tem momentos de descontração e cumplicidade e com quem aprende a datilografar e, por consequência, iniciar-se na escritura.

"Nasci não de um mas de vários túmulos. E um deles era um túmulo vivo" (BRUM, 2014:71). Menciona o bisavô que unindo-se a uma negra 
escrava teve uma filha Luzia, que se tornaria professora de seu pai. Os túmulos a que se refere a narradora correspondem às mortes de duas geraçóes: do bisavô e do avô. Seu pai torna-se órfẫo com apenas 11 anos e sozinho no hospital descobre a salvação pela leitura e também pela palavra escrita, preenchendo assim a morte do pai (avô da narradora). A figura da professora do pai, Luzia, a iluminada, que a narradora só conhecerá como lenda, iluminará também sua "linhagem", seu "lugar simbólico de pertencimento" (BRUM, 2014:77). É a partir da memória de Luzia que ela decide que sua vida de ora em diante estará ligada à palavra escrita.

Se não houve possibilidade de reconhecer-se como herdeira da mãe, que não se desligou nunca do túmulo da primeira filha morta, a narradora estabelece um vínculo de filiação intelectual com o pai, como ela também fascinado pelas letras e pela professora que "iluminou" seus primeiros passos no caminho da leitura. Em sua história com as palavras, com seus acontecimentos e desacontecimentos, fica claro que a decisão da narradora pela palavra escrita, que definiu sua trajetória identitária, deriva do amor do pai pelos livros e pelas letras. Ela, "a filha errada", cuja narrativa inicia com um confronto radical com o túmulo que roubou parte do encanto de sua infância, finaliza com uma "continuidade identificadora", para usar a expressão de Helmut Galle (2014: 199), com o pai e com a figura lendária de Luzia, a professora primária de seu pai. O livro realiza uma espécie de enquete sobre sua infância, o papel da mãe e do pai e das constantes mudanças, e sobretudo perscrutando a vida do pai para melhor entender a sua própria, mas termina por revelar a vocação da narradora como escritora. "Libertei as letras, e elas emergiram dos meus abismos como voragem. Voltei a escrever. Dessa vez uma vida para mim" (BRUM, 2014: 143).

Em Azul Corvo ${ }^{8}$ (2014), de Adriana Lisboa (1970), a memória atua como o fio condutor da narrativa, levando a protagonista-narradora, Evangelina (Vanja), por caminhos desconhecidos, revelando informaçôes sobre seu passado, assim como o de seus familiares, ao mesmo tempo em que articula as memórias de pessoas sem laços consanguíneos, mas pertencentes ao universo social e cultural percorrido pela protagonista, através da rememoração.

Joël Candau (2014: 140) enfatiza que "a memória familiar serve de princípio organizador da identidade do sujeito em diferentes modalidades", incluindo o "compartilhamento da vontade de compartilhar" e o "jogo da reapropriação do passado familiar”. Constatamos que Vanja pratica essas duas modalidades, pois encontra em Fernando, pai adotivo da protagonista, a vontade de compartilhamento e exercita a reflexão (re)elaborando a narrativa de sua vida.

\footnotetext{
${ }^{8}$ Primeira publicação em 2010 pela editora Rocco.
} 
O romance não apresenta uma ordem cronológica dos acontecimentos, ao contrário, o enredo caracteriza-se pela desordem, tendo como elemento articulador a memória, conferindo à escrita dos quinze capítulos uma semelhança com a maneira como as lembranças e esquecimentos assolam o rememorar articulado pela emoção.

O título Azul Corvo faz referência ao poema "The Fish" de Marianne Moore e também tem relação direta com a trajetória percorrida pela protagonista, indicando uma ligação entre o Brasil e os Estados Unidos, uma vez que a cor azul pode ser encontrada tanto nas conchas do mar de Copacabana, como nas penas dos corvos de Denver. O azul-corvo representaria o elo afetivo de Evangelina com os dois países, enquanto lugares que marcam de forma decisiva a constituição de sua identidade.

A personagem-narradora, Evangelina, aos vinte e dois anos de idade, resolve escrever sobre um período marcante de sua existência, seus treze anos, momento em que sua vida é sobressaltada por um acontecimento inesperado e irreversível: a morte da mãe, Suzana. Objetivando encontrar seu pai biológico, Vanja decide ir morar nos Estados Unidos (Denver, Colorado) com Fernando, ex-marido de sua mãe e que a registrou como filha.

Os acontecimentos revisitados são aqueles vivenciados por Vanja e, nesta rememoração, também se utiliza da memória de Fernando e de outros personagens para compor a narrativa, mesclando fatos individuais e coletivos, do passado distante com um presente latente. Nesse processo, são reveladas informaçóes que se tornaram fundamentais para o entendimento de sua existência que tornam-se basilares para seu processo identitário. Nesse sentido, Halbwachs (1997) enfatiza que é necessário para o indivíduo evocar seu próprio passado recorrer às lembranças de outras pessoas, sendo preciso se reportar a pontos de referência que extrapolam sua individualidade, que são determinados pela sociedade, promovendo, dessa forma, o enriquecimento de suas lembranças.

Na busca pela anterioridade materna, Vanja encontra-se com Fernando, que se revela um caminho para acessar as memórias do passado vivenciado por Suzana e, ao mesmo tempo, descobre fatos e acontecimentos históricos do Brasil, através tais relatos, comparando-os com os conteúdos trabalhados na escola no período em que viveu no Brasil. A mãe é a referência primeira na busca pela anterioridade e, no decorrer do percurso, cede espaço para Fernando, pois será nele que Vanja encontrará apoio para sua busca memorial familiar.

A ancestralidade serviu para identificar Vanja com sua mãe e com Fernando, embora ele não seja o pai biológico. $\mathrm{O}$ continuum revela-se fator primordial do romance memorial Azul Corvo, uma vez que a narradora adotou formas de agir e pensar da máe e de Fernando. Trata-se, portanto, da 
presença do continuum enfatizado por $\mathrm{Oz}$ e Salzberger (2015), assim como o emergir de vozes que surgem de longe, mencionado por Robin (1989). Importa mencionar a presença da memória cultural na narrativa, pois Vanja mescla, em seus mosaicos memoriais, informaçóes que pertencem à esfera familiar, íntima, tanto de Fernando quanto de Suzana, com informaçóes históricas pertencentes ao contexto brasileiro, tais como a Ditadura Militar e a Guerrilha do Araguaia.

(...) entre as coisas de que a gente lembra e as de que não se lembra, entre as que conhece e as que desconhece, é preciso tapar os buracos da memória com a estopa de que se dispóe. E talvez qualquer tentativa de conhecer o outro seja sempre isso, nossas mãos moldando tridimensionalidades, nosso desejo e incompetência montando um álbum de colagem para fazer levantar dali um morto. (LISBOA, 2014: 173-174)

No romance memorial Azul Corvo, as memórias genealógica e familiar encontram-se presentes de forma latente, uma vez que Vanja não ultrapassa três geraçóes, conforme destacou Candau $(2013 ; 2014)$. Vanja, por exercer o livre arbítrio, decide tornar-se herdeira e sucessora das trajetórias familiares, isto é, a da mãe Suzana e a do pai que a registrou, Fernando, as quais revelam-se como referências de vida para ela, delineando sua personalidade e seus posicionamentos perante a sociedade. Nesse processo de construção identitária, saberes e práticas são reapropriados, conforme a identificação e interesse de Vanja; é a manifestação da transmissão que realiza as acomodaçôes, conforme destacado por Muxel (1996).

Cabe ressaltar que o ponto chave do romance é a busca pela paternidade biológica de Vanja, a qual acaba se tornando secundária no decorrer da narrativa, cedendo lugar às descobertas geradas a partir dos diálogos e da amizade consolidada entre a narradora e Fernando. Tal situação reforça a afirmação de Candau (2014: 61) de que "Através da memória o indivíduo capta e compreende continuamente o mundo, manifesta suas intençóes a esse respeito, estrutura-o e coloca-o em ordem (tanto no tempo como no espaço) conferindo-lhe sentido".

\section{Reflexões finais}

O romance memorial ou de filiação, que emerge nas três últimas décadas, apresenta-se como uma forma narrativa centrada na anterioridade, ou seja, para entender-se enquanto indivíduo social e cultural, o narrador necessita reconstruir a trajetória de vida dos seus ascendentes, fazendo uso da memória como elemento principal desse acesso ao passado. É importante mencionar que, durante o processo de desvendamento de momentos cruciais da exis- 
tência dos ancestrais, elementos integrantes da memória familiar podem ser reforçados ou negligenciados, dependendo da situação em que se encontra o narrador no presente. Cabe-nos destacar que tal subgênero romancesco romance memorial e/ou de filiaçáo - difere do romance genealógico (saga), pois esse é narrado em terceira pessoa, por um narrador onisciente que segue uma ordem cronológica e linear dos acontecimentos, envolvendo as transformaçôes ocorridas em diversas geraçóes.

Dentre as conceituaçóes acerca da narrativa da anterioridade, Régine Robin (1989) introduz o conceito de romance memorial: aquele em que, através da recuperaçáo da memória dos antepassados, vem à tona a memória cultural de determinado período histórico, que insiste na valorização do sensível e do simbólico. Já Dominique Viart (2008) e Laurent Demanze (2008) classificam a narrativa da anterioridade como um gênero secundário, preferindo a apelação romance de filiação, "que trabalha a partir de investigaçóes subjetivas, de agenciamentos críticos e de tradiçóes narrativas" (DEMANZE, 2008: 13$){ }^{9}$

Uma das características primordiais do romance memorial e/ou de filiação é a evocação da memória cultural, uma vez que a narrativa está centrada em informaçóes familiares que fogem à esfera oficial, apelando para os vestígios (rastros) memoriais que resgatam as sensibilidades do convívio privado familiar, negligenciados dos discursos oficias.

O tema da transmissão - bem sucedida ou falha - constitui-se em aspecto nuclear do romance de filiação: os narradores se reapropriam da memória genealógica e familiar (aquela que abrange três geraçōes, no máximo) ou da memória geracional (a que ultrapassa o núcleo familiar e estende-se por diversas geraçóes), dando origem a um continnum verbal entre as geraçôes. Em certos casos operam-se rupturas que evidenciam o desejo em não reivindicar a herança familiar.

Azul Corvo de Adriana Lisboa integra o contexto do romance memorial no Brasil, pois além de apresentar as características evidenciadas na sua constituição, enfatiza de modo exemplar a busca pela anterioridade como meio de posicionar-se no mundo e, principalmente, situar-se como sujeito com uma identidade em contínuo processo de construção e desconstrução. A narradora, que ainda não é adulta, mas uma adolescente, investiga o passado desconhecido para ela de ativista político do pai adotivo, durante o período da ditadura militar brasileira, o que enseja o descobrimento de si mesma. Passa a entender melhor seus medos, fraquezas, atitudes e decisóes percebendo que a identidade é fluida e cambiante e que através dos rastros e vestígios memo-

\footnotetext{
9 “(...) un genre second qui travaille à partir d'investigations subjectives, d'agencements critiques e de traditions narratives."
} 
riais é possível revisitar o passado e escrever/registrar no presente os acontecimentos e transformações dos seus ascendentes e antepassados.

Olhos d'água de Conceição Evaristo, nascida em Belo Horizonte, mas radicada no Rio de Janeiro, trabalha, por um lado, em seu fazer literário no sentido de abrir para a filha os fragmentos dos arquivos memoriais que guarda da história de pobreza e superação de sua própria mãe e, por outro, em dar continuidade à genealogia literária de escritoras afro-brasileiras que a precederam, como Mirian Alves, leda Martins e Esmeralda Ribeiro, procurando com elas estabelecer o continuum verbal de que fala Amós Oz (2015). Sua obra poética, que vale a pena citar aqui, evidencia da mesma forma que sua contística a preocupação com a transmissão intergeracional:

A voz de minha bisavó ecoou

Criança

Nos poróes do navio.

Ecoou lamentos de uma infância perdida.

A voz de minha avó

Ecoou obediência

Aos brancos donos de tudo.

A voz de minha mãe

Ecoou baixinho revolta

No fundo das cozinhas alheias

Debaixo das trouxas

Roupagens sujas dos brancos

Pelo caminho empoeirado rumo à favela.

A minha voz ainda ecoa versos perplexos

Com rimas de sangue e fome.

A voz da minha filha

Recorre todas as nossas vozes

Recolhe em si

As vozes mudas caladas

Engasgadas nas gargantas.

A voz da minha filha

Recolhe em si

A fala e o ato.

O ontem - o hoje - o agora.

$\mathrm{Na}$ voz de minha filha

Se fará ouvir a ressonância

$\mathrm{O}$ eco da vida-liberdade.

Vozes mulheres. (EVARISTO, 2008)

Evaristo pinta com "tintas órfăs", parafraseando Laurent Demanze (2008), a história de suas ancestrais, recolhendo os rastros memoriais e preenchendo os vazios com a força de sua imaginação poética. É imperioso para a poeta, contista e romancista Conceição Evaristo recordar a trajetória de suas antepassadas porque sabe que somos o que lembramos e é essa herança de 
uma memória cultural vazada na história - feita "de sangue e fome" - que se inicia na travessia do Atlântico, que ela quer legar à filha que dela saberá recolher "a fala e o ato".

Meus desacontecimentos, a história de minha vida com as palavras, da gaúcha de Ijuí Eliane Brum, enquadra-se, segundo a classificação de Laurent Demanze (2008), no herdeiro problemático, aquele que, segundo o teórico francês, corresponde

ao escritor contemporâneo que constrói as narrativas de filiação, para exumar os vestígios de uma herança em farelos e alinhavar os farrapos de sua memória destruída. Entre transmissão ferida e herança de uma dívida, essas escritas de si reinventam uma identidade singular e plural ao mesmo tempo. (DEMANZE, 2008: 9). ${ }^{10}$

Esse mal-estar da transmissão no pungente texto de Eliane Brum se alinha à vertente da literatura francesa atual analisada por Laurent Demanze em Encres orphelines (2008: 21), onde o passado "se declina em figuras da herança impossível, da memória impedida ou da transmissão de uma dívida" ${ }^{11}$ Impedida de constituir-se em herdeira da mãe que nunca recuperou-se do luto da filha primogênita, a autora, de desacontecimento em desacontecimento, recolhe a herança fertilizadora do pai que a conduz pela trilha criadora da escritura.

Entre herdar e transmitir navegaram as três autoras da literatura contemporânea brasileira. Poderíamos nos perguntar como, no momento atual, tanto na literatura francesa quanto na brasileira, retornam questóes tão basilares e antigas como as de ascendência, memória, herança e transmissão? Creio que o interesse crescente e renovado pelas questôes ligadas à memória cultural, aos arquivos ficcionais e aos vestígios memoriais reinventaram as escritas de si que se voltam hoje mais para a anterioridade do que para a interioridade, como escreveu Dominique Viart (2008).

\section{Referências}

ARON, P. SAINT-JACQUES, D. VIALA, A. (eds.) Le Dictionnaire du littéraire. Paris: PUF, 2010.

ASSIS BRASIL, Luiz Antonio. Um castelo no pampa. I Perversas familias. Porto Alegre: Mercado Aberto, 1992. . II Pedra da memória. Porto Alegre: Mercado Aberto, 1993.

10 “(...) à l'écrivain contemporain qui échafaude des récits de filiation, pour exhumer les vestiges d'un héritage en miettes et raccommoder les lambeaux de sa mémoire déchirée. Entre transmission brisée et héritage d'une dette, ces écritures de soi réinventent une identité singulière et plurielle á la fois." 11 “(...) se décline tout à tour en figures de l'héritage impossible, de la mémoire empêchée ou de la transmission d'une dette." 
. III Os senhores do século. Porto Alegre: Mercado Aberto, 1994.

ASSMANN, Aleida. Espaços da recordação: formas e transformaçôes da memória cultural. Tradução: Paulo Soeth. Campinas: Unicamp, 2011.

AUDET, Noel. L’ombre de l'épervier. Québec: editions Québec/Amérique, 1988.

BERND, Zilá. "Romance memorial ou familiar e a memória cultural; a necessidade de transmitir em Um defeito de cor, de Ana Maria Gonçalves”. Revista Organon, Porto Alegre, I.L. UFRGS, n. 57, v. 29, jul.-dez.2014: 15-27.

BRUM, Eliane. Meus desacontecimentos, a história de minha vida com as palavras. São Paulo: LeYa, 2014.

CANDAU, Joël. Antropologia da memória. Lisboa: Instituto Piaget, 2013.

. Memória e identidade. São Paulo: Contexto, 2014.

CELlARD, K.; LAPOINTE, M-E. (dir.). Transmission et héritages de la littérature québécoise. Montréal: Presses de l'Université de Montréal, 2011.

DEMANZE, Laurent. Encres orphelines; Pierre Bergounioux, Gérard Macé, Pierre Michon. Paris: José Corti, 2008. (Col. Les Essais).

EVARISTO, Conceição. Olhos d'água. Rio de Janeiro: Pallas, 2015.

" "Vozes-mulheres". In: EVARISTO, Conceição. Poemas da recordaçâo e outros movimentos. Belo Horizonte: Nandyala, 2008.

GALLE, Helmut Paul Erich. "Evoluçóes do romance de família na atual literatura de língua alemä", Revista Organon: I.L. UFRGS, n. 57, v. 29, jul.-dez. 2014: 199-218.

GAGNEBIN, Jeanne Marie. "O rastro e a cicatriz: metáforas da memória”. In: GAGNEBIN, Jeanne Marie. Lembrar escrever esquecer. Sáo Paulo: editora 34, 2006: 107-118.

HALWACHS, Maurice. Mémoire collective. Édition critique établie par Gérard Namer. Paris: Albin Michel, 1997. (Edição original: Presses Universitaires de France, 1950)

LABERGE, Marie. Le goût du bonheur. Gabrielle. Montréal: Boréal, 2000.

. Le goût du bonheur. Adelaïde. Montréal: Boréal, 2001.

. Le goût du bonheur. Florent. Montreal: Boréal, 2001.

LE CLEZIO, Jean-Marie Gustave. L'Africain. Paris: Mercure de France, 2004.

LISBOA, Adriana. Azul corvo. Rio de Janeiro: Objetiva, 2014.

MASSAUD MOISÉS. "Roman-fleuve”. In: Dicionário de termos literários. 3. Ed. São Paulo: Cultrix, 1982: 461.

MUXEL, Anne. Individu et mémoire familiale. Paris: Armand Colin, 1996.

OZ, Amós; SAlZBERGER, Fania Oz. Os judeus e as palavras. São Paulo: Companhia das Letras, 2015.

PREUMON, Yannick. "Roman familial”. In: ARON, P. SAINT-JACQUES, D. VIALA, A. (eds.) Le Dictionnaire du littéraire. Paris: PUF, 2010: 528-529. 
ROBIN, Régine. Le roman mémoriel. Montréal: Le Préambule, 1989. (Col. L'Univers des discours)

VIART, Dominique. "Récits de filiation”. In: VIART, D.; VERCIER, B. La littérature française au présent. 2. Ed. Paris: Bordas, 2008: 79-102.

WIKIPÉDIA. Yabas. Disponível em: <https://pt.wikipedia.org/wiki/Yabas>. Acesso em: 21 jan. 2016.

Zilá Bernd. Doutor em Letras (USP) com Pós-doutorado (Université de Montréal, Canadá); Professora e orientadora do PPG-Memória Social e Bens Culturais do Unilasalle/Canoas - RS; Bolsa PQ/Cnpq - Nível 1B; foi presidente da ABECAN (Associação Brasileira de Estudos Canadenses) e do ICSS-CIEC (Conseil International d'études canadiennes). Foi fundadora e primeira editora da Revista Interfaces BrasilCanadá. É Officier de l'Ordre National du Québec et Officier des Palmes Académiques do Governo francês.

E-mail: zilabster@gmail.com

Tanira Rodrigues Soares. Doutoranda do PPG-Memória Social e Bens Culturais do Unilasalle/Canoas - RS e Servidora Técnica Administrativa da Universidade Federal do Rio Grande do Sul - UfRGS. Mestre Profissional em Memória Social e Bens Culturais pelo Unilasalle/Canoas - RS, Especialista em Literatura Brasileira pela UFRGS e em Metodologia do Ensino em História e Geografia pela Universidade Regional Integrada do Alto Uruguai e das Missóes (URI).

E-mail: tanira_soares@yahoo.com.br 